\title{
Phytochemical Profiling of Hemidesmus indicus (L.) R. Br. ex Schult and its Antioxidant, Anti-Inflammatory and Neuroprotection Linked Enzyme Inhibitory Properties
}

\author{
Swati Som ', Justin Antony'2, S Palanisamy Dhanabal ${ }^{3}$, Sivasankaran Ponnusankar ${ }^{1, *}$
}

Swati Som', Justin Antony²,

S Palanisamy Dhanabal ${ }^{3}$,

Sivasankaran Ponnusankar ${ }^{1, *}$

'Department of Pharmacy Practice, JSS

College of Pharmacy, JSS Academy of Higher

Education \& Research, Ooty, Tamilnadu

643001, INDIA.

2Department of Pharmacology, JSS College

of Pharmacy, JSS Academy of Higher

Education \& Research, Ooty, Tamilnadu

643001, INDIA.

${ }^{3}$ Department of Pharmacognosy and

Phytochemistry, JSS College of Pharmacy,

JSS Academy of Higher Education \& Research

Ooty, Tamilnadu 643001, INDIA

\section{Correspondence}

Sivasankaran Ponnusankar

Professor \& Head, Department of

Pharmacy Practice, JSS College of

Pharmacy, Ooty, Tamilnadu, 643001

INDIA.

E-mail: ponnusankarsivas@gmail.com

\section{History}

- Submission Date: 19-10-2020;

- Review completed: 22-11-2020;

- Accepted Date: 08-12-2020.

DOI : 10.5530/pj.2021.13.28

Article Available online

http://www.phcogj.com/v13/i1

Copyright

() 2021 Phcogi.Com. This is an openaccess article distributed under the terms of the Creative Commons Attribution 4.0 International license.

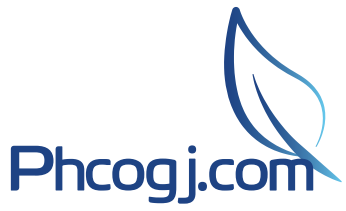

\begin{abstract}
Introduction: Exponential expansion in the usage of herbal medicines was observed in recent decades due to the increasing importance of the traditionally used natural remedies. In order to identify bioactive components of medicinal value, in the present study, we aimed to screen different extracts of Hemidesmus indicus (L.) R. Br. ex Schult for health beneficial effect by exploring its biological properties and phytochemical profile. Methods: By using sequential extraction method, $H$. indicus roots were extracted with various solvents based on low to high polarity. Subsequently, quantitative phytochemical profiling, antioxidant and enzyme inhibitory activities were tested by using standard protocols. The MTT assay was carried out in SHSY-5Y cell lines to evaluate anti-inflammatory effect. Results: Methanol extract displayed highest phytochemical content with high concentration of terpenoid $(59.82 \pm 0.97 \mathrm{mg} \mathrm{LE} / \mathrm{g}$ of extract) and saponin ( $15.03 \pm 0.45 \mathrm{mg} \mathrm{DE} / \mathrm{g}$ of extract). All the extracts exhibited concentration dependent pharmacological activities. In comparison, methanol extract produced highest activities with $\mathrm{IC}_{50}$ of $15.21 \pm 0.31$ and $11.36 \pm 0.39 \mu \mathrm{g} / \mathrm{ml}$ against $\mathrm{NO}$ and DPPH radical scavenging assays respectively. Also, methanol extract showed maximum inhibition against acetylcholinesterase $\left(I C_{50}=17.46 \pm 0.49 \mu \mathrm{g} / \mathrm{ml}\right)$ and butyrylcholinesterase $\left(I C_{50}=31.05 \pm 0.39 \mu \mathrm{g} / \mathrm{ml}\right)$, however, aqueous extract displayed highest potency against monoamine oxidase- $B$ inhibition $\left(I C_{50}=24.60 \pm 0.45\right.$ $\mu \mathrm{g} / \mathrm{ml}$ ). At $12.5-100 \mu \mathrm{g} / \mathrm{mL}$ concentrations, methanol and aqueous extracts did not show any cytotoxic effect on SH-SY5Y cells and dose dependently suppressed TNF- $\alpha$ and IL-6 production. Conclusion: Collectively, $\mathrm{H}$. indicus could act as a disease modifying therapeutic in pharmaceutical industries by utilizing it as alternative therapy for the management of oxidative stress and its related disorders.
\end{abstract}

Key words: Hemidesmus indicus, Antioxidant, Acetylcholinesterase, Butyrylcholinesterase, Monoamine oxidase.

\section{INTRODUCTION}

Herbal medicine has been widely embraced since the prehistoric times and was used as dominant form of medical care by the ancient practitioner. Despite a long history of effective use, western medicine took over the world due to lack of scientific evidences in the context of contemporary medicines. ${ }^{1}$ In recent years, a surge of acceptance of natural therapies and public interest was observed because of serious side effects associated with long term usage of conventional medicines. Besides, absence of curatives for chronic diseases encourages the advent of natural remedies. ${ }^{2}$ As a result, global use of herbal medicinal products and nutraceuticals has been expanded across the developing and industrialized countries and often been viewed as a balanced approach of healing. ${ }^{3-5}$

Growing environmental stress results in accumulation of free radicals, which becomes the reason for the generation of lethal diseases such as Alzheimer's disease (AD), Parkinson's disease (PD), cancer etc. ${ }^{6}$ Restoration of redox homeostasis serves a great deal in maintenance of health and prevention of various diseases. ${ }^{7}$ With increasing evidence of a wider range of safety, naturally derived antioxidants have gained its popularity over the decades. Plant derived antioxidant preserves active physiological state by efficiently scavenging the free radical generated in the cells and strengthen the defence system. ${ }^{8}$ Recently, exogenous antioxidants from dietary sources with enzyme inhibitory properties has been considered as a promising strategy to suppress oxidative stress and its associated disorders. ${ }^{9}$ Hence, in the quest of searching for the suitable natural antioxidant, we investigated the antioxidant potential of Hemidesmus indicus (L.) R. $\mathrm{Br}$. ex Schult, in order to explore its value as a suitable traditional medicine or as a source of pharmaceutical compounds.

Belonging to a phylogenetic genus, Hemidesmus indicus (L.) R. Br. ex Schult (Apocynaceae), commonly known as Anantmula or Indian sarsaparilla, is an indigenous plant of India and Sri Lanka. This popularly ingested aromatic shrub has been served as sharbat (drink) and as a flavouring agent for the preparation of soft drink and as perfumery in cosmetic industry. ${ }^{10}$ Apart from consumption as food, $H$. indicus is an integral part of Ayurveda and Siddha medicinal system and known

Cite this article: Som S, Antony J, Dhanabal SP, Ponnusankar S. Phytochemical Profiling of Hemidesmus indicus (L.) R. Br. ex Schult and its Antioxidant, Anti-Inflammatory and Neuroprotection Linked Enzyme Inhibitory Properties. Pharmacog J. 2021;13(1): 196-205. 
to have numerous health profitable benefits such as anti-inflammatory, anti-asthmatic, antibacterial, antinoniceptive, anti-hyperglycemic, anti-atherogenic, anti-spasmodic anti-hepatotoxic, antipyretic, antiepileptic, antidiarrhoeal, immunopotentiating and antiulcerogenic properties. Moreover, it was also documented to be used as a traditional remedy for leucorrhoea, gonorrhea, syphilis, impotence, gastrointestinal disorders, fever, cough, jaundice, blood disorders, bronchitis, and poisoning. ${ }^{11-15}$ Earlier reports represent the presence of a mixture of therapeutic phytocompounds such as terpenoids, tannins, phenols, flavonoids and saponins in the $H$. indicus roots, which could provide synergistic action towards its pharmacological properties. ${ }^{16}$ Majority of the studies conducted previously, involved the qualitative aspects of the plant and meagre attempt has been made to understand the varying impact of solvents on quantification of the phytochemical profile of this species. ${ }^{17}$ Therefore, our objective is to deal with quantitative insights of the phytoconstituents present with respect to different polarities of solvent, which might offer a great help in understanding its biological potential.

Over the last centuries, several epidemiological, preclinical and clinical studies have demonstrated that there is a close relationship between oxidative stress, neurodegenerative disorders and inflammation. ${ }^{18,19}$ Enzyme inhibition is considered to be the most effective strategy for the discovery of bioactive molecules for cognitive enhancement. For instance, inhibition of cholinesterase and monoamine oxidase enzymes assists as a primary treatment for the management of $\mathrm{AD}$ and PD respectively. ${ }^{20}$ Similarly, inhibition of uncontrolled response of inflammatory mediators to the tissue injury leads to protection against oxidative stress and prevent augmentation of its related disorders including neurodegenerative diseases. ${ }^{21}$ Hence, the current study is designed to evaluate the effect of different extraction solvent on the phytochemical profile of Anantmula and to investigate its antioxidant, anti-inflammatory and enzyme inhibitory capacity for the development of natural antioxidant of nutraceuticals and pharmaceutical importance.

\section{MATERIALS AND METHODS}

\section{Plant material}

Dried roots of $H$. indicus were gathered from local markets of Nilgiris district, India and was authenticated by Dr. S. Rajan, field botanist, Central Council for Research in Homeopathy, Department of AYUSH, The Nilgiris, Tamilnadu, India. The voucher specimen was deposited at Department of Pharmacognosy and Phytopharmacy, JSS College of Pharmacy, Udhagamandalam 643001, India.

\section{Chemicals}

The chemicals and solvents utilized for the experiments were procured from Sigma-Aldrich.

\section{Preparation of root extracts}

Fresh roots were air dried and coarsely powdered. Obtained powder was soaked in a conical flask with pet ether, chloroform, ethyl acetate, methanol and water on the basis of increasing polarity of solvents and kept in a mechanical shaker (100 rpm, at room temperature) for $72 \mathrm{~h}$ followed by filtration with Whatman filter paper. Later on, under high pressure, each filtered extract was concentrated by a rotary evaporator at a maximal temperature of $35^{\circ} \mathrm{C}$. All the extracts were protected from light and stored at $4{ }^{\circ} \mathrm{C}$ for further use. ${ }^{22}$

\section{Phytochemical profiling}

\section{Determination of the total phenol content (TPC)}

Phenolic content in the different extracts of $H$. indicus was determined by adopting the method described by Singleton and Rossi. ${ }^{23}$ A mixture of $10 \%$ Folin-Ciocalteau's reagent $(2.5 \mathrm{~mL})$ and $2 \%$ sodium carbonate solution $(2 \mathrm{~mL})$ was added to different extracts $(0.5 \mathrm{~mL})$ of $H$. indicus $(1 \mathrm{mg} / \mathrm{mL})$. After incubation for $15 \mathrm{~min}$ at $45{ }^{\circ} \mathrm{C}$, absorbance was measured at $765 \mathrm{~nm}$. Based on the calibration curve prepared using gallic acid as standard, total phenol content was calculated.

\section{Determination of total flavonoid contents (TFC)}

Aluminium chloride $\left(\mathrm{AlCl}_{3}\right)$ colorimetric method was used in order to determine total flavonoid content. Different extracts of $H$. indicus $(1 \mathrm{~mL})$ was added to the mixture of methanol $(3 \mathrm{~mL}), 10 \% \mathrm{AlCl}_{3}(0.2$ $\mathrm{mL})$, potassium acetate $(1 \mathrm{M})(0.2 \mathrm{~mL})$, and distilled water $(5.6 \mathrm{~mL})$. Absorbance was read at $420 \mathrm{~nm}$ after $30 \mathrm{~min}$. Based on a standard curve prepared using rutin as standard, total flavonoid content was measured. ${ }^{24}$

\section{Determination of total tannin contents (TTC)}

By using the method developed by Sun (1998), total tannin content was measured where a mixture of extract $(1 \mathrm{~mL})$ and acidic methanol $(3$ $\mathrm{mL}$ ) was allowed to stand for $10 \mathrm{~min}$ at room temperature followed by addition of Vanillin $\mathrm{HCl}$ reagent $(6 \mathrm{~mL})$. Absorbance was measured at $500 \mathrm{~nm}$. Quantification of total tannin was done on the basis of standard curve of catechin as standard..$^{25}$

\section{Determination of total terpenoid contents (TTRC)}

Total terpenoid content in the different extracts of $H$. indicus was quantified based on the method described by Narayan Ghorai et al. ${ }^{26}$ To the assay mixture of extract $(160 \mu \mathrm{L})$ and chloroform $(1.2 \mathrm{~mL})$, conc. $\mathrm{H}_{2} \mathrm{SO}_{4}$ was slowly added and incubated for $2 \mathrm{~h}$ at room temperature. The supernatant of reaction mixture was decanted and 95\% methanol $(1.5 \mathrm{~mL})$ was added to dissolve the resultant reddish brown precipitate and absorbance was recorded at $538 \mathrm{~nm}$. Total terpenoid content was determined with the aid of standard curve of linalool as standard.

\section{Determination of total saponin contents (TSC)}

For estimation of total saponin content in the extract, vanillinsulphuric acid assay was incorporated. Extracts $(0.25 \mathrm{~mL})$ were mixed with $8 \%(\mathrm{w} / \mathrm{v})$ vanillin in ethanol $(0.25 \mathrm{~mL})$ and $72 \%(\mathrm{v} / \mathrm{v})$ sulphuric acid in water $(2.5 \mathrm{~mL})$ and incubated at $60{ }^{\circ} \mathrm{C}$ in water bath for 15 min. Absorbance was then measured at $560 \mathrm{~nm}$ after cooling at room temperature for 5 min. ${ }^{27}$

\section{Antioxidant activity}

\section{Nitric oxide (NO) scavenging activity}

To sodium nitroprusside solution ( $1 \mathrm{~mL}$ of $25 \mathrm{mM}$ ), $4 \mathrm{~mL}$ of different concentrations $(6.25-100 \mu \mathrm{g} / \mathrm{mL})$ of extracts was added and incubated for $3 \mathrm{~h}$ at $37^{\circ} \mathrm{C}$. Griess reagent $(0.3 \mathrm{~mL})$ was added to the solution $(0.5 \mathrm{~mL})$ and the absorbance of the chromophore formed was measured at $570 \mathrm{~nm}$. Control was prepared in a similar way, but without the extract. Butylated hydroxytoluene (BHT) was used as a reference standard. ${ }^{28}$

\section{1, 2-diphenyl-2-picryl hydrazyl (DPPH) scavenging activity}

Effect of $H$. indicus extracts on DPPH radical has been carried out by employing the method described earlier by Mary et al. ${ }^{29} 2 \mathrm{~mL}$ of various concentrations $(2 \mathrm{~mL})$ of extracts $(6.25-100 \mu \mathrm{g} / \mathrm{mL})$ was mixed with DPPH $(0.5 \mathrm{~mL}$ of $0.01 \mathrm{M})$ in methanol. Absorbance of the solution was analysed at $517 \mathrm{~nm}$. Ascorbic acid was used as reference standard.

\section{Neuroprotective potential}

\section{Evaluation of Acetylcholinesterase (AChE) Butyrylcholinesterase (BuChE) inhibition assay} and

Both AChE and BuChE inhibitory ability of the extracts was evaluated by a modified colorimetric method of Ellman et al. ${ }^{30}$ Reaction 
mixture consisting of 5,5-dithiobis-2-nitrobenzoate ( $125 \mu \mathrm{L}$ of $3 \mathrm{mM})$, acetylthiocholine iodide ( $25 \mu \mathrm{Lof} 15 \mathrm{mM})$, different concentrations $(6.25-100 \mu \mathrm{g} / \mathrm{mL})$ of extracts and phosphate buffer $\mathrm{pH} 8.0(50 \mu \mathrm{L}$ of $0.1 \mathrm{M})$ was incubated at $25^{\circ} \mathrm{C}$. After $20 \mathrm{~min}$, AChE $(25 \mu \mathrm{L}$ of $0.22 \mathrm{U} /$ $\mathrm{mL})$ or BuChE $(25 \mu \mathrm{L}$ of $0.22 \mathrm{U} / \mathrm{mL})$ was added to initiate the reaction and the activity was determined by measuring absorbance at $412 \mathrm{~nm}$. Galantamine was used as standard.

\section{Evaluation of monoamine oxidase (MAO) inhibition assay}

Monoamine oxidase (MAO) inhibitory activity was performed according to the fluorescence method as described by Diermen et al., and Novaroli et al. ${ }^{31,32}$ For the inhibition assay, reaction was carried out in black 96-well microtitre plates, where each well contained kynuramine $(8 \mu \mathrm{L}$ of $0.75 \mathrm{M})$, MAO-A $(0.015 \mathrm{mg} / \mathrm{mL})$ or MAO-B enzyme $(0.015 \mathrm{mg} / \mathrm{mL})(50 \mu \mathrm{L})$ and $2 \mu \mathrm{L}$ of various concentrations of extract $(6.25-100 \mu \mathrm{g} / \mathrm{mL}$ ) prepared in dimethylsulfoxide (DMSO) (final concentration of $1 \% \mathrm{DMSO})$. To the mixture, $140 \mu \mathrm{L}$ of $0.1 \mathrm{M}$ potassium phosphate buffer ( $\mathrm{pH} \mathrm{7.4)}$ was added and incubated at $37^{\circ} \mathrm{C}$ for $20 \mathrm{~min}$. Reaction was terminated by addition of $\mathrm{NaOH}(75 \mu \mathrm{L}$ of $2 \mathrm{~N})$ followed by centrifugation at $12000 \mathrm{rpm}$ for $10 \mathrm{~min}$. Fluorescence reading was measured at $400 \mathrm{~nm}$. Clorgyline and pargyline were chosen as standard inhibitors of MAO-A and MAO-B, respectively.

\section{Cell viability assay}

By using 3-(4,5-dimethylthiazol-2-yl)-2,5-diphenyl-tetrazolium bromide (MTT) assay, cytotoxic effect of $H$. indicus extracts on SHSY5Y cells was determined. All cell culture experiments were performed in a humidified atmosphere containing $5 \% \mathrm{CO}_{2}$ at $37^{\circ} \mathrm{C}$, in Dulbecco's Modified Eagle's Medium (DMEM), supplemented with $10 \%$ fetal bovine serum and $1 \%$ penicillin-streptomycin. Predetermined number of cells $\left(2 \times 10^{4} /\right.$ well $)$ were seeded in 96 -well plate, cultured with or without $1 \mu \mathrm{g} / \mathrm{mL}$ lipopolysaccharide (LPS) and incubated for $24 \mathrm{~h}$ at $37^{\circ} \mathrm{C}$. Different concentrations of methanol and aqueous extracts, prepared in DMSO, were dispensed into the plates containing LPS. The cells cultured for $24 \mathrm{~h}$ without adding LPS under the same conditions were used as a control. After $24 \mathrm{~h}$, fresh medium was added with $0.5 \%$ MTT solution and the plates were incubated for $3 \mathrm{~h}$. Further, $10 \%$ sodium lauryl sulphate dissolved in $0.1 \mathrm{~mol} / \mathrm{L} \mathrm{HCl}$ was added to terminate the reaction and absorbance was measured at $550 \mathrm{~nm}$ with a microplate reader ${ }^{33}$

\section{Determination of tumor necrosis factor (TNF-a) and interleukin 6 (IL-6) levels}

Different concentrations of methanol and aqueous extracts of $H$. indicus were incubated overnight in the 96-well plate containing $1 \mu \mathrm{L} /$ mL LPS treated SH-SY5Y cells at $4{ }^{\circ} \mathrm{C}$. Based on the ELISA kit manual, concentration of tumor necrosis factor (TNF- $\alpha$ ) and interleukin 6 (IL6) was estimated with an ELISA reader.

\section{Statistical analysis}

All experiments were done in triplicates and were analysed using SPSS for Windows (version 17.0, SPSS Inc., Chicago, IL, USA). All values were expressed as mean \pm standard deviation (SD). Correlation analyses were performed using Pearson's Correlation Coefficient. Mean values were compared using the one-way analysis of variance (ANOVA) and $P<0.05$ was considered statistically significant.

\section{RESULTS}

\section{Phytochemical analysis}

The percentage yield of different extracts of $H$. indicus roots obtained after successive maceration extraction with polar and non-polar solvents varied from $4.49 \%$ to $33.23 \%$ (mass of extract/mass of roots). The highest yield was obtained from aqueous extract followed by methanol extract, suggesting presence of high amount of polar compounds soluble in methanol and water solvents. Total yield obtained with regards to the different solvents used for extraction was as follows: water> methanol $>$ ethyl acetate $>$ chloroform $>$ pet ether (Table 1). Results from the quantitative phytochemical analysis indicated that terpenoids and phenols constituted the major fraction ranging from 13.51 to $59.82 \mathrm{mg}$ $\mathrm{LE} / \mathrm{g}$ and 3.57 to $45.40 \mathrm{mg} \mathrm{GAE} / \mathrm{g}$ of extract respectively. In addition, based on the data expressed in Table 2, all the crude extracts showed a substantial amount of flavonoid and saponin content ranging from 0.88 to $23.22 \mathrm{mg} \mathrm{RE} / \mathrm{g}$ and 1.39 to $15.03 \mathrm{mg} \mathrm{DE} / \mathrm{g}$ of extract respectively, whereas tannin content was quantified in the least amount in the plant roots. As evident from our study, in comparison, methanol and aqueous extracts showed maximum amount of phytochemical content where methanol extract exhibited relatively high concentration of terpenoids $(59.82 \pm 0.97 \mathrm{mg} \mathrm{LE} / \mathrm{g}$ of extract) and saponins $(15.03 \pm 0.45 \mathrm{mg} \mathrm{DE} / \mathrm{g}$ of extract), whereas aqueous extract displayed adequate amount of phenols (45.40 $\pm 0.08 \mathrm{mg} \mathrm{GAE} / \mathrm{g}$ of extract) and flavonoids (23.22 \pm 0.37 $\mathrm{mg} \mathrm{RE} / \mathrm{g}$ of extract) (Table 2).

\section{Antioxidant activity}

In the present study, we have validated antioxidant activity of $H$. indicus by using NO scavenging test and DPPH reducing capacity. We detected that all the five extracts of $H$. indicus roots displayed radical scavenging activity in a concentration dependent manner. Amid all, methanolic extract predominantly produced potent $\mathrm{NO}\left(\mathrm{IC}_{50}=15.21 \pm 0.31 \mu \mathrm{g} / \mathrm{ml}\right)$ and $\mathrm{DPPH}\left(\mathrm{IC}_{50}=11.36 \pm 0.39 \mu \mathrm{g} / \mathrm{ml}\right)$ scavenging activity when compared to reference drug BHT $\left(\mathrm{IC}_{50}=1.30 \pm 0.21 \mu \mathrm{g} / \mathrm{ml}\right)$ and ascorbic acid $\left(\mathrm{IC}_{50}=\right.$ $0.99 \pm 0.42 \mu \mathrm{g} / \mathrm{ml}$ ) respectively (Table 3 ). Surprisingly, aqueous extract also displayed strong radical scavenging activity and exhibited $\mathrm{IC}_{50}$ of $19.14 \pm 0.67$ and $28.91 \pm 0.22 \mu \mathrm{g} / \mathrm{ml}$ against $\mathrm{NO}$ and $\mathrm{DPPH}$ scavenging assays. However, on the contrary, pet ether and chloroform extracts revealed lowest antioxidant activity. Further, in order to evaluate the relation between phytoconstituents and antioxidant activity, we have performed correlation studies by calculating Pearson's correlation coefficients which indicated TPC, TTRC and TFC have a significant correlation with both the antioxidant assays (Table 5).

\section{Neuroprotective potential}

\section{Acetylcholinesterase (AChE) and Butyrylcholinesterase (BuChE) inhibition assays}

Based on our exploratory study, we can convey that, methanol extract of $\mathrm{H}$. indicus demonstrated the highest $\mathrm{AChE}$ and $\mathrm{BuChE}$ inhibitory activity with $\mathrm{IC}_{50}$ of $(17.46 \pm 0.49 \mu \mathrm{g} / \mathrm{mL})$ and $(31.05 \pm 0.39 \mu \mathrm{g} / \mathrm{mL})$ respectively. Likewise, aqueous extracts too showed equally satisfactory results against $\mathrm{AChE}\left(\mathrm{IC}_{50}=21.19 \pm 0.4 \mu \mathrm{g} / \mathrm{mL}\right)$ and $\mathrm{BuChE}\left(\mathrm{IC}_{50}\right.$ $=39.23 \pm 0.11 \mu \mathrm{g} / \mathrm{mL}$ ), while, pet ether extract displayed marginal inhibition potential (Table 4). Interestingly, a significant correlation was observed between $\operatorname{AChE}(\mathrm{R}=-0.888)$ and $\mathrm{BuChE}(\mathrm{R}=-0.915)$ inhibitory activities and concentration of TTRC (Table 5).

\section{Monoamine oxidase inhibition assays}

The effect of the extracts on the MAO inhibition is presented in the Table 4. From our experiment, we can conclude that all the extracts have displayed dose dependent enzyme inhibitory activity against MAO-B. However, none of the extracts showed any remarkable MAO-A inhibitory effect. Results from MAO-A enzyme inhibition analysis is contradictory to our antioxidant and anti-cholinesterase studies. However, the reason behind the conflict is unknown. Surprisingly, unlike other assays, aqueous extract $\left(\mathrm{IC}_{50}=24.60 \pm 0.45\right.$ $\mu \mathrm{g} / \mathrm{mL}$ ) manifested potent inhibitory activity against MAO-B than methanol extract $\left(\mathrm{IC}_{50}=55.01 \pm 0.56 \mu \mathrm{g} / \mathrm{mL}\right)$. Correlation coefficient studies indicated a significant relation between MAO-B inhibition and concentration of TPC $(\mathrm{R}=-0.881)$ and TFC $(\mathrm{R}=-0.850)$ (Table 5). 
Som, et al:: Phytochemical Profiling of Hemidesmus indicus (L.) R. Br. ex Schult and its Antioxidant, Anti-Inflammatory and Neuroprotection Linked Enzyme Inhibitory Properties

Table 1: Extraction yield of different extracts of $\boldsymbol{H}$. indicus roots.

\begin{tabular}{cccccc}
\hline & Pet ether & Chloroform & Ethyl acetate & Methanol & Water \\
\hline \% yield & 4.49 & 6.45 & 11.11 & 27.87 & 33.23 \\
\hline
\end{tabular}

Table 2: Quantitative phytochemical analysis of different extracts of $\boldsymbol{H}$. indicus roots.

\begin{tabular}{|c|c|c|c|c|c|}
\hline & Pet ether & Chloroform & Ethyl acetate & Methanol & Water \\
\hline TPC (mg GAE/g) & $3.57 \pm 0.22^{\mathrm{a}}$ & $9.93 \pm 0.1^{\mathrm{a}}$ & $16.29 \pm 0.16^{b}$ & $40.95 \pm 0.6^{c}$ & $45.40 \pm 0.08^{c}$ \\
\hline TFC (mg RE/g) & $0.88 \pm 0.38^{\mathrm{a}}$ & $2.19 \pm 0.73^{\mathrm{a}}$ & $6.58 \pm 0.55^{\mathrm{b}}$ & $19.09 \pm 0.6^{\mathrm{b}}$ & $23.22 \pm 0.37^{c}$ \\
\hline TTC (mg CE/g) & $0.22 \pm 0.09^{\mathrm{a}}$ & $0.86 \pm 0.15^{\mathrm{a}}$ & $1.36 \pm 0.15^{\mathrm{a}}$ & $4.61 \pm 0.2^{\mathrm{b}}$ & $2.33 \pm 0.22^{\mathrm{a}}$ \\
\hline TTRC (mg LE/g) & $13.51 \pm 0.78^{\mathrm{a}}$ & $18.13 \pm 0.64^{\mathrm{a}}$ & $25.97 \pm 0.16^{\mathrm{b}}$ & $59.82 \pm 0.97^{\mathrm{d}}$ & $48.94 \pm 0.82^{c}$ \\
\hline TSC (mg DE/g) & $1.39 \pm 0.37^{\mathrm{a}}$ & $2.63 \pm 0.15^{\mathrm{a}}$ & $6.59 \pm 0.47^{\mathrm{b}}$ & $15.03 \pm 0.45^{\mathrm{d}}$ & $10.33 \pm 0.33$ \\
\hline
\end{tabular}

Each value represents average of three analysis (mean $\pm \mathrm{SD}$ ). Values with different letters (a-d) in the same row indicated significant difference $(P<0.05)$. TPC-total phenolic content, TFC-total flavonoid content, TTC- total tannin content, TTRC-total terpenoid content, TSC-total saponin content, GAE-Gallic acid equivalents, RE-Rutin equivalents, CE-Catechin equivalents, LE-Linalool equivalents, DE- Diosgenin equivalents.

Table 3: $\mathrm{IC}_{50}$ values of different extracts of $\boldsymbol{H}$. indicus roots for radical scavenging and anti-inflammatory assays.

\begin{tabular}{ccc}
\hline Extracts & $\mathrm{NO}$ & $\mathrm{DPPH}$ \\
& $\mathrm{IC}_{50}(\mu \mathrm{g} / \mathrm{mL})$ & $\mathrm{IC}_{50}(\mu \mathrm{gg} / \mathrm{mL})$ \\
\hline Pet ether & $87.62 \pm 0.54^{\mathrm{a}}$ & $106.23 \pm 0.44^{\mathrm{a}}$ \\
chloroform & $67.40 \pm 0.47^{\mathrm{b}}$ & $94.23 \pm 0.75^{\mathrm{a}}$ \\
ethyl acetate & $51.89 \pm 0.22^{\mathrm{b}}$ & $78.81 \pm 0.66^{\mathrm{b}}$ \\
methanol & $15.21 \pm 0.31^{\mathrm{c}}$ & $11.36 \pm 0.39^{\mathrm{d}}$ \\
water & $19.14 \pm 0.67^{\mathrm{c}}$ & $28.91 \pm 0.22^{\mathrm{c}}$ \\
BHT & $1.30 \pm 0.21^{\mathrm{d}}$ & - \\
Ascorbic acid & - & $0.99 \pm 0.42^{\mathrm{e}}$ \\
Diclofenac & - & - \\
\hline
\end{tabular}

The values are expressed as mean \pm SD of three independent experiments. Values with different letters $(a-e)$ in the same column indicated significant difference $(P<0.05)$.

Table 4: IC ${ }_{50}$ values of different extracts of $\boldsymbol{H}$. indicus for cholinesterase and monoamine oxidase inhibition assays.

\begin{tabular}{ccccc}
\hline Extracts & AChE & BuChE & MAO-A & MAO-B \\
\hline Pet ether & $111.01 \pm 0.67^{\mathrm{a}}$ & $146.20 \pm 0.55^{\mathrm{a}}$ & $239.59 \pm 0.45^{\mathrm{a}}$ & $108.92 \pm 0.22^{\mathrm{a}}$ \\
chloroform & $59.65 \pm 0.33^{\mathrm{b}}$ & $85.51 \pm 0.21^{\mathrm{c}}$ & $215.83 \pm 0.41^{\mathrm{a}}$ & $113.96 \pm 0.78^{\mathrm{a}}$ \\
ethyl acetate & $90.78 \pm 0.45^{\mathrm{a}}$ & $104.09 \pm 0.23^{\mathrm{b}}$ & $217.38 \pm 0.67^{\mathrm{a}}$ & $57.91 \pm 0.86^{\mathrm{b}}$ \\
methanol & $17.46 \pm 0.49^{\mathrm{c}}$ & $31.05 \pm 0.39^{\mathrm{d}}$ & $205.68 \pm 0.48^{\mathrm{a}}$ & $55.01 \pm 0.56^{\mathrm{b}}$ \\
water & $21.19 \pm 0.45^{\mathrm{c}}$ & $39.23 \pm 0.11^{\mathrm{d}}$ & $154.78 \pm 0.23^{\mathrm{b}}$ & $24.60 \pm 0.45^{\mathrm{c}}$ \\
Galantamine & $0.18 \pm 0.84^{\mathrm{d}}$ & $3.23 \pm 0.67^{\mathrm{e}}$ & - & - \\
clorgyline & - & - & $5.91 \pm 0.33^{\mathrm{c}}$ & - \\
L-deprenil & - & - & - & $2.02 \pm 0.39^{\mathrm{d}}$ \\
\hline
\end{tabular}

The values are expressed as mean \pm SD of three independent experiments. Values with different letters (a-e) in the same column indicated significant difference $(P<0.05)$.

Table 5: Correlation coefficient between phytochemical compounds and antioxidant, anti-inflammatory, cholinesterase and MAO-B inhibitory activities of $H$. indicus roots.

\begin{tabular}{|c|c|c|c|c|c|c|}
\hline \multirow{2}{*}{ Assays } & \multicolumn{2}{|c|}{ TPC } & \multicolumn{2}{|c|}{ TTRC } & \multicolumn{2}{|c|}{ TFC } \\
\hline & $r$ & $\mathrm{P}$ & $r$ & $\mathrm{P}$ & $r$ & $\mathrm{P}$ \\
\hline NO & -0.976 & $0.033^{*}$ & -0.969 & 0.289 & -0.979 & $0.043^{*}$ \\
\hline DPPH & -0.973 & 0.675 & -0.999 & $0.0321^{\star}$ & -0.987 & 0.343 \\
\hline Anti-inflammatory & -0.973 & $0.043^{*}$ & -0.999 & $0.039^{*}$ & -0.986 & $0.028^{\star}$ \\
\hline AChE & -0.906 & 0.677 & -0.888 & $0.0028^{\star *}$ & -0.839 & 0.989 \\
\hline BuChE & -0.925 & 0.578 & -0.915 & $0.0443^{*}$ & -0.890 & 0.879 \\
\hline MAO-B & -0.881 & $0.036^{*}$ & -0.796 & 0.698 & -0.850 & $0.048^{*}$ \\
\hline
\end{tabular}

${ }^{*}$ indicates $P<0.01$ and ${ }^{*} P<0.05$. TPC-total phenolic content, TFC-total flavonoid content, TTRC-total terpenoid content 


\section{Cell viability assay}

Since from all the aforementioned assays, best result was exhibited by methanol and aqueous extracts, hence both of the extracts were further subjected to subsequent experiments. Results from the cell viability assay displayed that at concentrations of $12.5-100 \mu \mathrm{g} / \mathrm{mL}$, both the extract showed no cytotoxic effect on SH-SY5Y cells and displayed $>90 \%$ of viability. However, at the concentration of $200 \mu \mathrm{g} / \mathrm{mL}$, slight reduction in cell viability was observed for both the extracts. Based on the outcome from cell viability assay, we have used 25-100 $\mu \mathrm{g} /$ $\mathrm{mL}$ concentrations of both methanol and aqueous extracts for other experiments on SH-SY5Y cells (Figure 1).

\section{Determination of TNF- $a$ and IL- 6 levels}

Treated SH-SY5Y cells with only LPS significantly increased the levels of TNF- $\alpha(1111.67 \pm 29.67 \mu \mathrm{g} / \mathrm{mL})$ and IL-6 $(11548.67 \pm 57.4 \mu \mathrm{g} / \mathrm{mL})$ when compared to control. As expected, both the extracts showed concentration dependent suppression of cytokines production. However, on comparison, highest inhibitory activities against TNF- $a$ $(351.33 \pm 71.49 \mu \mathrm{g} / \mathrm{mL})$ and IL-6 $(2639 \pm 36.51 \mu \mathrm{g} / \mathrm{mL})$ in LPS treated SH-SY5Y cells was displayed by $100 \mu \mathrm{g} / \mathrm{mL}$ of methanol extract (Figure $2,3)$.

\section{DISCUSSION}

A Plethora of studies has witnessed the protective role of herbals against several chronic diseases. Based on the epidemiological and clinical evidences, phytochemicals have shown to affect cell integrity and redox status by modulating the cellular metabolism and antioxidant enzyme expression. ${ }^{34}$ In this context, the objective of the present study intended to explore the phytochemical profile of $H$. indicus quantitatively and validate its radical scavenging, anti-inflammatory and enzyme inhibitory capacity linked to neuroprotection.

Interaction between bioactive phytoconstituents depends upon its solubility, chemical structures and polarities of solvents used during extraction. ${ }^{17}$ Hence, to investigate the medicinal value of $H$. indicus, we have analyzed the effect of extracting solvents on its phytochemical content. Although, there were several documents available on qualitative identification of phytochemicals in $H$. indicus but information on quantitative data was limited. Polyphenols and terpenoids are the major phytoconstituents isolated by various researchers from the roots, which is in correspondence to our findings. ${ }^{35-38}$ Results from our phytochemical profiling studies indicated appreciable amount of polyphenols, terpenoids, flavonoids and saponins. Similar results were observed previously, but with the variable amount. ${ }^{39}$ The probable reason behind

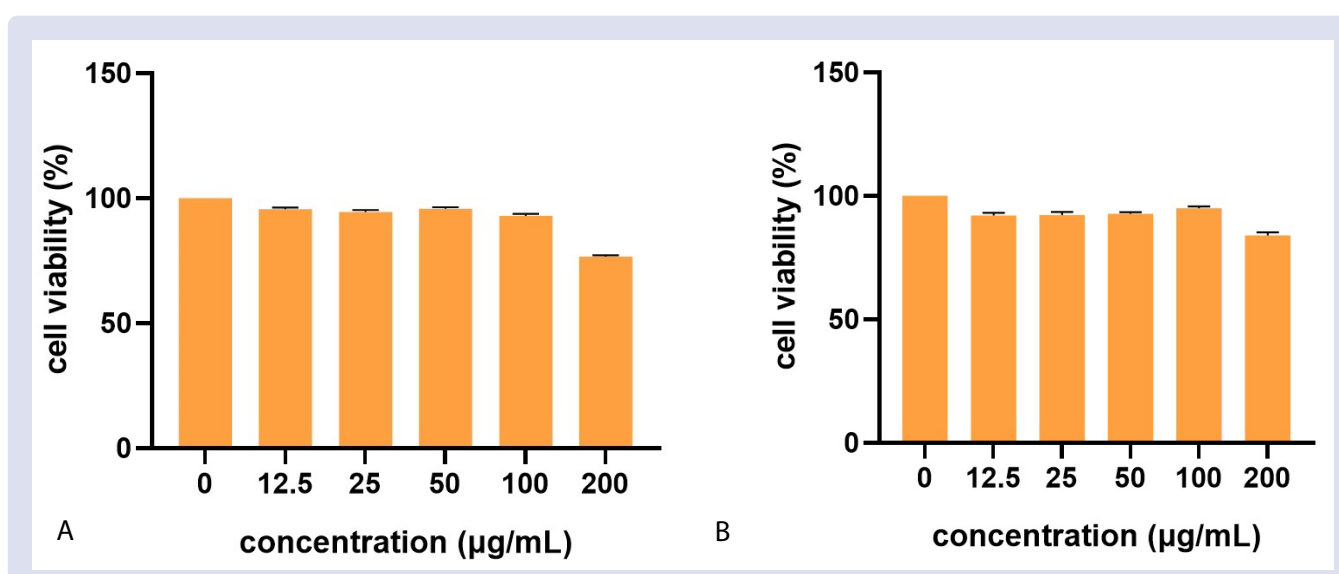

Figure 1: (A) Effect of methanol extract of $H$. indicus on the viabilities of SH-SY5Y neuroblastoma cells. (B) Effect of aqueous extract of $H$. indicus on the viabilities of SH-SY5Y neuroblastoma cells.

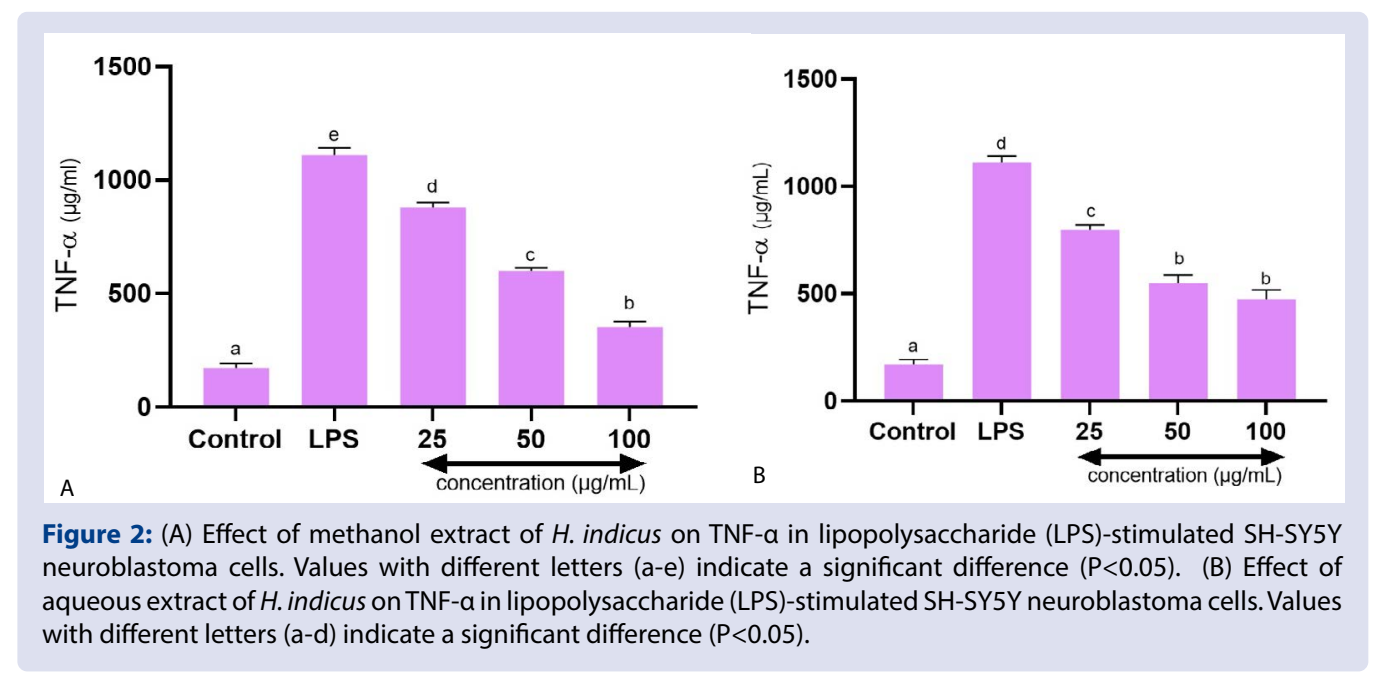




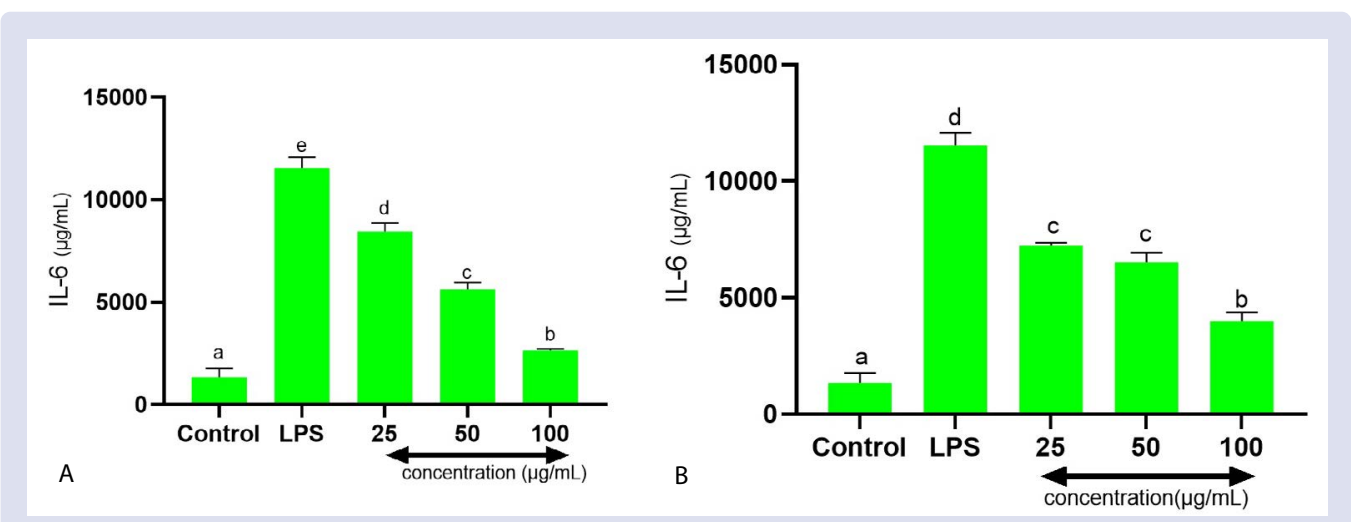

Figure 3: (A) Effect of methanol extract of $H$. indicus on IL-6 in lipopolysaccharide (LPS)-stimulated SH-SY5Y neuroblastoma cells. Values with different letters $(a-e)$ indicate a significant difference $(P<0.05)$. (B) Effect of aqueous extract of $H$. indicus on IL- 6 in lipopolysaccharide (LPS)-stimulated SH-SY5Y neuroblastoma cells. Values with different letters $(a-d)$ indicate a significant difference $(P<0.05)$.

the variation in content could be due to edafoclimatic effect and/or use of different extraction and analytical techniques. Presence of mixture of phytochemicals in $H$. indicus roots, when acting in combination, could be accountable for its health beneficial properties.

The generation of free radicals in-vivo is a constant phenomenon either due to physiological metabolism or pathological alterations. Aberrant accumulation and generation of free radicals or reactive oxygen species (ROS) contributes to the damage of intracellular and extracellular matrix components such as proteins, lipids, proteoglycans and collagens, which leads to the development of oxidative stress and its related diseases. ${ }^{40}$ Antioxidants potentially counteract this deleterious effects of ROS, providing protection against oxidative stress and maintain ion homeostasis, thereby, sustain the physiological functions of cells. ${ }^{41}$ Therefore, we checked the antioxidant activity of $H$. indicus and noticed that the polar extracts have manifested good free radical neutralization ability. Both methanol and aqueous extracts displayed strong radical scavenging and reducing property against NO and DPPH tests, followed by ethyl acetate extract. However, almost no antioxidant effect was observed in the pet ether extract. Our results are in accordance with the previously accomplished studies, suggesting presence of quantifiable amount of terpenoid and phenol compounds in $H$. indicus, synergistically could attribute to the potent antioxidant activity due to their redox properties, possibly through hydrogen atom, electron-proton and sequential proton loss-electron transfer mechanisms. ${ }^{42-49}$

Natural antioxidant protects from a wide range of lethal diseases such as $\mathrm{AD}$ by inhibiting hyper accumulation of ROS. Oxidative stress triggers neuronal cell apoptosis and creates neurotoxic environment which hinders the brain functions, supporting neurodegeneration. ${ }^{50,51}$ Loss of cholinergic synapses results in decrease of $\mathrm{ACh}$ and $\mathrm{BuCh}$ levels in the brain regions, which appeared to be the major element in the development of $\mathrm{AD}$ and the first thing experienced by the patients suffering from the disease. ${ }^{52}$ Restoration of these neurotransmitter levels by inhibiting $\mathrm{AChE}$ and $\mathrm{BuChE}$ enzymes is the current therapy accepted worldwide. However, side effects associated with currently available AChE and BuChE inhibitors encouraged scientific investigation for identification of potent inhibitors from herbal sources in an effort to discover new AD drugs..$^{53,54}$ Although, very few studies were conducted previously on the choline esterase activity of $H$. indicus indicating some extent of neuroprotective property by its methanol and hydroalcoholic extracts, but no attempt has been made to measure these activities of the plant with a combination of solvents. ${ }^{10,37}$ Therefore, we investigated the effect of different solvents on cholinesterase inhibitory properties of $H$. indicus by employing AChE and BuChE inhibitory assays. From our exploratory study, we found that methanol and aqueous extracts of $H$. indicus have demonstrated the highest AChE and BuChE inhibitory activities followed by chloroform extract, while pet ether and ethyl acetate extracts showed minimal effect. As suggested by Mukherjee et al., terpenes possess a carbon skeleton which is susceptible to hydrophobic interactions with the hydrophobic active site of AChE and BuChE and thus contribute to the anti-cholinesterase activities. ${ }^{55}$ Results from our Pearson's Correlation Coefficient study and the presence of ample quantity of terpenoids in methanol extract found from our quantitative phytochemical experiments, support the aforementioned findings. In addition, outcomes of our cholinesterase inhibition test are in agreement with our antioxidant studies, suggesting that the extracts with higher scavenging potential have a direct impact on AChE and BuChE inhibition activity. Although more research is needed to understand the underlying mechanism.

Excessive production of monoamine oxidase (MAO) lead to the neuronal injury and aggravates the oxidative stress condition in the cells. ${ }^{56}$ Earlier studies have demonstrated that selective inhibition of two isoforms of MAO i.e., MAO-A and MAO-B could be a potential therapeutic strategy in the management of neurological disorders, where MAO-A inhibitors are helpful in the treatment of depression and mood disorders and MAO-B inhibitors provide protection against $\mathrm{AD}$ and $\mathrm{PD} .{ }^{57}$ In our experiment, different root extracts have shown dose dependent $\mathrm{MAO}-\mathrm{B}$ inhibition, but highest was exhibited by aqueous extract followed by methanol extract. However, no remarkable activity was produced by any extract against MAO-A inhibition. Previously, several reports have indicated that phenols are potent reversible MAO-B inhibitors with different mode of inhibition such as non-competitive, competitive, or mixed-type inhibition. ${ }^{57}$ Besides, flavonoids have been widely reported for its MAO enzyme inhibition activity due to its structural similarities with synthetic MAO inhibitors. ${ }^{58}$ Thus, the highest inhibitory effect of aqueous extract correlates with the high phenolic and flavonoid content when compared to the methanol extract. Altogether, methanol and aqueous extracts of $H$. indicus could be promising candidate for the drug development against neurodegenerative disorders and its related complications.

Evaluation of cytotoxicity potential of the extracts act as an important tool for identification of bioactive molecule. Hence, in order to exclude any probable cytotoxic effects, methanol and aqueous extracts of $H$. indicus were subjected to cell viability assay on SH-SY5Y neuroblastoma cells which indicated no cytotoxicity at the $12.5-100 \mu \mathrm{g} /$ mL concentrations.

Inflammation functions as doubled edged sword, as it provide protection against many harmful stimuli and helps repair tissue 
damage, while on other hand, excessive secretion of inflammatory mediators such as TNF $-\alpha$ and IL- 6 can exacerbate the oxidative stress and its related disorders. ${ }^{59}$ Results from the present study demonstrated that both methanol and aqueous extracts of $H$. indicus dosedependently reduced TNF $-\alpha$ and IL-6 levels in LPS treated SH-SY5Y cells, however, on comparison, best result was exhibited by methanol extract. These results are in accordance to the previously conducted studies and supported that both the extracts could be potential target for the development of anti-inflammatory drugs. ${ }^{60-62}$ Studies conducted earlier demonstrated that terpenoids are capable of producing antiinflammatory properties by suppressing nuclear transcription factor $\kappa \mathrm{B}(\mathrm{NF}-\kappa \mathrm{B})$ pathway, which is considered to be a major regulator of the immune system and inflammatory response. Reason behind the inhibitory effect of terpenoids is due to the presence of $\alpha$ - $\beta$-unsaturated carbonyl functions which act as NF- $\mathrm{kB}$ inhibitory pharmacophore and thereby either acts directly on I $\kappa \mathrm{B}$ kinase (IKKs), on the proteosome machinery, or on the NF- $\kappa \mathrm{B}$-DNA binding. ${ }^{63}$ Likewise, few researchers have reported that phenolic compounds along with flavonoids have shown desirable anti-inflammatory property by inhibiting COX activity or its gene expression or by up/downregulating crucial inflammatory transcriptional factors, like NF- $\kappa B$ or nuclear factor erythroid 2related factor 2 (Nrf-2). ${ }^{64}$ Our results are in agreement with these reports and signified that presence of the rich amount of secondary metabolites, especially phenols and terpenoids, as reported from our quantitative phytochemical investigations, could be responsible for the anti-inflammatory activity of the extracts. However, the compounds present in the extracts and their mechanism behind these advantageous effects of the extracts need to be explored.

\section{CONCLUSION}

The present study, for the first time, reveals the effect of different extracting solvents on phytochemical content, antioxidant, antiinflammatory and neuroprotection linked enzymes (MOA-B, AChE, $\mathrm{BuChE}$ ) inhibitory properties of $H$. indicus. In the light of our findings, it can be concluded that based on our phytochemical profiling studies, terpenoids and phenols were identified as a major class of secondary metabolites present in the plant roots. Besides, amid all, methanol and aqueous extracts exhibited highest amount of these phytochemical compounds which strongly correlates with the performed pharmacological activities. However, further investigation is required to find active components from these extracts. Collectively, results from our study represents the dietary and medicinal importance of $H$. indicus and thus could be a promising source of natural antioxidants for the utilization in the food, pharmaceutical and cosmetic industries.

\section{DECLARATION OF COMPETING INTEREST}

None.

\section{ABBREVIATIONS}

AD: Alzheimer's disease (AD); PD: Parkinson's disease (PD); MTT: 3-(4,5-dimethylthiazol-2-yl)-2,5-diphenyl-tetrazolium bromide; NO: Nitric oxide; DPPH: 1, 2-diphenyl-2-picryl hydrazyl; ROS: Reactive oxygen species; TPC: Total phenol content; TFC: total flavonoid contents; TTC: Total tannin contents; TTRC: Total terpenoid contents; TSC: Total saponin contents; AChE: Acetylcholinesterase; BuChE: Butyrylcholinesterase; MAO: Monoamine oxidase; LPS: lipopolysaccharide; TNF- $\alpha$ : Tumor necrosis factor; IL-6: interleukin 6; ELISA: Enzyme-linked Immune Sorbent Assay; ANOVA: Analysis of variance.

\section{ACKNOWLEDGEMENT}

We express our gratitude to the Department of Pharmacognosy and Phytochemistry, Department of Pharmacology and Department of
Pharmaceutical Biotechnology, JSS College of Pharmacy, Ooty for providing various chemicals and facilities used during the course of the study. This project was financially supported by the Lady Tata Memorial Trust, Mumbai, INDIA with Senior Research Fellowship to Ms. Swati Som.

\section{REFERENCES}

1. Pan SY, Pan S, Yu ZL, Ma DL, Chen SB, Fong WF, Han YF, Ko KM. New perspectives on innovative drug discovery: an overview. J Pharm Pharm Sci. 2010;13(3):450-71. doi: 10.18433/j39w2g.

2. Pan SY, Litscher G, Gao SH, Zhou SF, Yu ZL, Chen HQ, Zhang SF, Tang MK, Sun $\mathrm{JN}, \mathrm{Ko} \mathrm{KM}$. Historical perspective of traditional indigenous medical practices: the current renaissance and conservation of herbal resources. Evid Based Complement Alternat Med. 2014;2014:525340. doi: 10.1155/2014/525340.

3. Ekor $M$. The growing use of herbal medicines: issues relating to adverse reactions and challenges in monitoring safety. Front Pharmacol. 2014 Jan 10;4:177. doi: 10.3389/fphar.2013.00177.

4. Bandaranayake WM. Quality control, screening, toxicity, and regulation of herbal drugs, In Modern Phytomedicine: Turning Medicinal Plants into Drugs, Eds. Germany: Wiley-VCH Verlag GmbH \& Co. KGaA: Weinheim, p. 25-57; 2006.

5. Bodeker G, Cora N, Chi-Keong O, Grundy B, Burford G, Shein K, Kin. WHO global atlas of traditional, complementary and alternative medicine, Kobe, Japan : WHO Centre for Health Development; 2006.

6. Jaradat NA, Al-Masri M, Zaid AN, Hussein F, Al-Rimawi F, Mokh AA, Ghonaim $\mathrm{S}$. Phytochemical, antimicrobial and antioxidant preliminary screening of a traditional Palestinian medicinal plant, Ononis pubescens. L Eur J Integr Med. 2017 Sep;14: 46-51. doi:10.1016/j.eujim.2017.08.012

7. Ursini F, Maiorino M, Forman HJ. Redox homeostasis: The Golden Mean of healthy living. Redox Biol. 2016 Aug;8:205-15. doi: 10.1016/j.redox.2016.01.010.

8. Foyer $\mathrm{CH}$, Noctor $\mathrm{G}$. Redox homeostasis and antioxidant signaling: a metabolic interface between stress perception and physiological responses. Plant Cell. 2005 Jul;17(7):1866-75. doi: 10.1105/tpc.105.033589.

9. Padhan B, Nayak JK, Panda D. Natural antioxidant potential of selected underutilized wild yams (Dioscorea spp.) for health benefit. J Food Sci Technol. 2020 Jun;57(6):2370-2376. doi: 10.1007/s13197-020-04470-x.

10. Kundu A, Mitra A. Flavoring extracts of Hemidesmus indicus roots and Vanilla planifolia pods exhibit in vitro acetylcholinesterase inhibitory activities. Plant Foods Hum Nutr. 2013 Sep;68(3):247-53. doi: 10.1007/s11130-013-0363-z.

11. Fulzele SV Bhurchandi PM, Kanoje VM, Joshi SB, Dorle AK. Immunostimulant activity of Ashtamangal ghrita in rats. Indian J Pharmacol. 2002;34:194-197.

12. Mary NK, Babu BH, Padikkala J. Antiatherogenic effect of Caps HT2, a herbal Ayurvedic medicine formulation. Phytomedicine. 2003;10(6-7):474-82. doi: 10.1078/094471103322331412.

13. Periyanayagam K, Venkatarathnakumar $T$, Nagaveni A, Subitha VG, Sundari $P_{1}$ Vaijorohini M, Umamaheswari $V$. Topical anti-inflammatory activity of pinda thailam, a herbal gel formulation. Anc Sci Life. 2004 Jul;24(1):1-5.

14. Dey A, De JN. Anti-snake Venom Botanicals Used by the Ethnic Groups of Purulia District, West Bengal, India. J Herbs Spices Med Plants. 2012;18(2):152 165. doi: 10.1080/10496475.2011.652298.

15. Das S, Bisht SS. The bioactive and therapeutic potential of Hemidesmus indicus R. Br. (Indian Sarsaparilla) root. Phytother Res. 2013 Jun;27(6):791-801. doi: 10.1002/ptr.4788.

16. Nandy S, Mukherjee A, Pandey DK, Ray P, DeyA. Indian Sarsaparilla (Hemidesmus indicus): Recent progress in research on ethnobotany, phytochemistry and pharmacology. J Ethnopharmacol. 2020 May 23;254:112609. doi: 10.1016/j. jep.2020.112609

17. Thouri A, Chahdoura H, El Arem A, Omri Hichri A, Ben Hassin R, Achour L. Effect of solvents extraction on phytochemical components and biological activities of Tunisian date seeds (var. Korkobbi and Arechti). BMC Complement Altern Med. 2017 May 4;17(1):248. doi: 10.1186/s12906-017-1751-y.

18. Nwidu LL, Elmorsy E, Aprioku JS, Siminialayi I, Carter WG. In Vitro AntiCholinesterase and Antioxidant Activity of Extracts of Moringa oleifera Plants from Rivers State, Niger Delta, Nigeria. Medicines (Basel). 2018 Jul 5;5(3):71. doi: 10.3390/medicines5030071.

19. Chougouo RD, Nguekeu YM, Dzoyem JP, Awouafack MD, Kouamouo J, Tane P, McGaw LJ, Eloff JN. Anti-inflammatory and acetylcholinesterase activity of extract, fractions and five compounds isolated from the leaves and twigs of Artemisia annua growing in Cameroon. Springerplus. 2016 Sep 9:5(1):1525. doi: 10.1186/s40064-016-3199-9.

20. Asghari B, Zengin G, Bahadori MB, Abbas-Mohammadi M, Dinparast Amylase, glucosidase, tyrosinase, and cholinesterases inhibitory, antioxidant effects, and GC-MS analysis of wild mint (Mentha longifolia var. calliantha) essential oil: A natural remedy. Eur J Integr Med. 2018 Sep:22:44-49. doi:10.1016/j.eujim.2018.08.004 
21. Chen L, Deng H, Cui H, Fang J, Zuo Z, Deng J, LiY, Wang X, Zhao L. Inflammatory responses and inflammation-associated diseases in organs. Oncotarget. 2017 Dec 14;9(6):7204-7218. doi: 10.18632/oncotarget.23208.

22. Jaradat N, Al-Lahham S. Phytochemical profile, antimicrobial, antioxidant and antiobesity activities of Scolymus angiospermus Gaertn. Four fractions from Jericho/Palestine. J Complement Integr Med. 2018 Feb 28;15(3):/j/jcim.2018.15. issue-3/jcim-2017-0127/jcim-2017-0127.xml. doi: 10.1515/jcim-2017-0127.

23. Singleton VL, Rossi JA. Colorimetric of total phenolics with phosphomolybdicphosphotungstic acid reagents. Am J Enol Vinic. 1965;16:144-158.

24. Köksal E, Gülçin I. Antioxidant activity of cauliflower (Brassica oleracea L.). Turk J Agric For. 2008;32: 65-78.

25. Sun B, Richardo-Da-Silvia JM, Spranger I. Critical factors of vanillin assay for catechins and proanthocyanidins. J Agric Food Chem. 1998 Sep 24;46(10):426774. doi: 10.1021/jf980366

26. Narayan Ghorai CS, Gucchait S, Kumar SS, Suman B. Estimation of total Terpenoids concentration in plant tissues using a monoterpen, Linalool as standard reagent. Protocol Exchange. 2012;005 doi:10.1038/protex.2012.055.

27. Hiai $S$, Oura $H$, Nakajima T. Color reaction of some sapogenins and saponins with vanillin and sulfuric acid. Planta Med. 1976 Mar;29(2):116-22. doi: 10.1055/ s-0028-1097639.

28. Ebrahimzadeh MA, Nabavi SF, Nabavi SM. Antioxidant activities of methano extract of Sambucus ebulus L. flower. Pak J Biol Sci. 2009 Mar 1:12(5):447-50. doi: 10.3923/pjbs.2009.447.450

29. Koleva II, van Beek TA, Linssen JP, de Groot A, Evstatieva LN. Screening of plant extracts for antioxidant activity: a comparative study on three testing methods. Phytochem Anal. 2002 Jan-Feb;13(1):8-17. doi: 10.1002/pca.611.

30. Ellman GL, Courtney KD, Andres V, Feather-stone RM. A new and rapid colorimetric determination of acetylcholinesterase activity. Biochem Pharmacol. 1961 Jul;7:88-95. doi: 10.1016/0006-2952(61)90145-9

31. van Diermen D, Marston A, Bravo J, Reist M, Carrupt PA, Hostettmann K Monoamine oxidase inhibition by Rhodiola rosea L. roots. J Ethnopharmacol. 2009 Mar 18;122(2):397-401. doi: 10.1016/j.jep.2009.01.007.

32. Novaroli L, Reist M, Favre E, Carotti A, Catto M, Carrupt PA. Human recombinant monoamine oxidase $B$ as reliable and efficient enzyme source for inhibitor screening. Bioorg Med Chem. 2005 Nov 15;13(22):6212-7. doi: 10.1016/j.bmc.2005.06.043

33. Hwang ES, Thi ND. Antioxidant and anti-inflammatory activities of Orostachys japonicas. Asian Pac J Trop Biomed. 2020;10(11):516-22. doi: 10.4103/2221 1691.294092

34. Sakat S, Juvekar AR, Gambhire MN. In vitro antioxidant and anti-inflammatory activity of methanol extract of Oxalis corniculata Linn. Int J Pharm Pharm Sci. 2010;2(1):146-155.

35. Heo JR, Lee GA, Kim GS, Hwang KA, Choi KC. Phytochemical-induced reactive oxygen species and endoplasmic reticulum stress-mediated apoptosis and differentiation in malignant melanoma cells. Phytomedicine. 2018 Jan 15:39:100-110. doi: 10.1016/j.phymed.2017.12.006.

36. Jayaram S, Dharmesh SM. Assessment of antioxidant potentials of free and bound phenolics of Hemidesmus indicus (L) R. Br against oxidative damage. Pharmacognosy Res. 2011 Oct;3(4):225-31. doi: 10.4103/0974-8490.89741.

37. Gupta MM, Verma RK, Misra LN. Terpenoids from Hemidesmus indicus. Phytochemistry. 1992;31(11):4036-4037. doi:10.1016/S0031-9422(00)97582-4

38. Penumala M, Zinka RB, Shaik JB, Mallepalli SKR, Vadde R, Amooru DG Phytochemical profiling and in vitro screening for anticholinesterase, antioxidant, antiglucosidase and neuroprotective effect of three traditional medicinal plants for Alzheimer's Disease and Diabetes Mellitus dual therapy. BMC Complement Altern Med. 2018 Mar 2;18(1):77. doi: 10.1186/s12906-018-2140-x.

39. Joshi A, Lad H, Sharma H, Bhatnagar D. Evaluation of phytochemical composition and antioxidative, hypoglycaemic and hypolipidaemic properties of methanolic extract of Hemidesmus indicus roots in streptozotocin-induced diabetic mice. Clin Phytosci. 2018;4(7). doi:10.1186/s40816-018-0064-0

40. Khanna VG, Kannabiran K. Larvicidal effect of Hemidesmus indicus, Gymnema sylvestre and Eclipta prostrate against Culex quinquifaciatus mosquito larvae. Afr J Biotechnol. 2007;6(3):307-311. doi:10.4314/ajb.v6i3.56207.

41. Wolff SP, Jiang ZY, Hunt JV. Protein glycation and oxidative stress in diabetes mellitus and ageing. Free Radic Biol Med. 1991;10(5):339-52. doi: 10.1016/08915849(91)90040-a.

42. Alzoubi KH, Khabour OF, Salah HA, Hasan Z. Vitamin E prevents high-fat highcarbohydrates diet-induced memory impairment: the role of oxidative stress. Physiol Behav. 2013 Jul 2;119:72-8. doi: 10.1016/j.physbeh.2013.06.011.

43. Shahidi F, Wanasundara PK. Phenolic antioxidants. Crit Rev Food Sci Nutr. 1992;32(1):67-103. doi: 10.1080/10408399209527581
44. Islam MR, Reza AA, Chawdhury KAA, Uddin J, Farhana K. Evaluation of in vitro antioxidant activity and cytotoxicity of methanolic extract of Sida cordata leaves. Int J Biol Pharm Res. 2014;5(2):196-200.

45. Gonçalves S, Moreira E, Grosso C, Andrade PB, Valentão P, Romano A. Phenolic profile, antioxidant activity and enzyme inhibitory activities of extracts from aromatic plants used in Mediterranean diet. J Food Sci Technol. 2017 Jan;54(1):219-227. doi: 10.1007/s13197-016-2453-z.

46. Sultana S, Khan N, Sharma S, Alam A. Modulation of biochemical parameters by Hemidesmus indicus in cumene hydroperoxide-induced murine skin: possible role in protection against free radicals-induced cutaneous oxidatve stress and tumor promotion. J Ethnopharmacol. 2003 Mar:85(1):33-41. doi: 10.1016/S0378-8741(02)00360-4

47. Saravanan N, Nalini N. Antioxidant effect of Hemidesmus indicus on ethanolinduced hepatotoxicity in rats. J Med Food. 2007 Dec;10(4):675-82. doi: 10.1089/jmf.2006.110.

48. Ravishankara MN, Shrivastava N, Padh H, Rajani M. Evaluation of antioxidant properties of root bark of Hemidesmus indicus R. Br. (Anantmul). Phytomedicine. 2002 Mar;9(2):153-60. doi: 10.1078/0944-7113-00104.

49. Rao GMM, Venkateswararao C, Rawat AKS, Pushpangadan P, Shirwaikar A Antioxidant and antihepatotoxic activities of Hemidesmus indicus R. Br. Acta Pharm Turc. 2005:47(2):107-113.

50. Serrano F, Klann E. Reactive oxygen species and synaptic plasticity in the aging hippocampus. Ageing Res Rev. 2004 Nov;3(4):431-443. doi:10.1016/j. arr.2004.05.002

51. Tuzcu M, Baydas G. Effect of melatonin and vitamin $E$ on diabetes-induced learning and memory impairment in rats. Eur J Pharmacol. 2006 May 10;537(13):106-10. doi: 10.1016/j.ejphar.2006.03.024

52. Loizzo MR, Tundis R, Menichini F, Menichini F. Natural products and thei derivatives as cholinesterase inhibitors in the treatment of neurodegenerative disorders: an update. Curr Med Chem. 2008:15(12):1209-28. doi: 10.2174/092986708784310422.

53. Rogers SL, Farlow MR, Doody RS, Mohs R, Friedhoff LT. A 24-week, doubleblind, placebo-controlled trial of donepezil in patients with Alzheimer's disease. Donepezil Study Group. Neurology. 1998 Jan;50(1):136-45. doi: 10.1212/ wnl.50.1.136.

54. Mehta M, Adem A, Sabbagh M. New acetylcholinesterase inhibitors for Alzheimer's disease. Int J Alzheimers Dis. 2012;2012:728983. doi: $10.1155 / 2012 / 728983$

55. Mukherjee PK, Kumar V, Mal M, Houghton PJ. Acetylcholinesterase inhibitors from plants. Phytomedicine. 2007 Apr;14(4):289-300. doi: 10.1016/1. phymed.2007.02.002

56. Thomas T. Monoamine oxidase-B inhibitors in the treatment of Alzheimer's disease. Neurobiol Aging. 2000 Mar-Apr:21(2):343-8. doi: 10.1016/s01974580(00)00100-7.

57. Yamada $M$, Yasuhara $H$. Clinical pharmacology of $M A O$ inhibitors: safety and future. Neurotoxicology. 2004 Jan;25(1-2):215-21. doi: 10.1016/S0161813X(03)00097-4.

58. Carradori S, Gidaro MC, Petzer A, Costa G, Guglielmi P, Chimenti P, Alcaro S, Petzer JP. Inhibition of Human Monoamine Oxidase: Biological and Molecular Modeling Studies on Selected Natural Flavonoids. J Agric Food Chem. 2016 Nov 30;64(47):9004-9011. doi: 10.1021/acs.jafc.6b03529.

59. Anoop MV, Bindu AR. In-vitro anti-inflammatory activity studies on Syzygium zeylanicum (L) DC leaves. International Journal of Pharmacology Research\& Review. 2015;4(8):18-27.

60. Vijayalakshmi K, Shyamala R, Thirumurugan V, Sethuraman M, Rajan S, Badam S, Mukherjee PK. Physico-Phytochemical investigation and Anti-inflammatory screening of Capsicum annum L. and Hemidesmus indicus (Linn.) R. Br. Anc Sci Life. 2010 Apr;29(4):35-40.

61. Mehta A, Sethiya NK, Mehta C, Shah GB. Anti-arthritis activity of roots of Hemidesmus indicus R.Br. (Anantmul) in rats. Asian Pac J Trop Med. 2012 Feb;5(2):130-5. doi: 10.1016/S1995-7645(12)60011-X.

62. Pathan JK, Gautam G, Gupta AK. Investigation of Anti-inflammatory activity of Hemedesmus indicus L. on Carrageenan induced paw oedema in rats. Journal of Drug Delivery and Therapeutics, 2018;8(5):92-494. doi:10.22270/jddt. v8i5.1912

63. de las Heras B, Hortelano S. Molecular basis of the anti-inflammatory effects of terpenoids. Inflamm Allergy Drug Targets. 2009 Mar;8(1):28-39. doi $10.2174 / 187152809787582534$

64. Sergent T, Piront N, Meurice J, Toussaint O, Schneider YJ. Anti-inflammatory effects of dietary phenolic compounds in an in vitro model of inflamed human intestinal epithelium. Chem Biol Interact. 2010 Dec 5;188(3):659-67. doi 10.1016/j.cbi.2010.08.007 


\section{GRAPHICAL ABSTRACT}

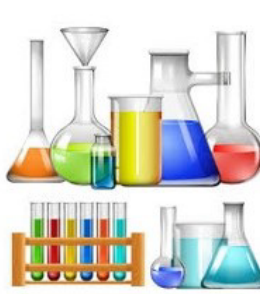

Phytochemical profiling

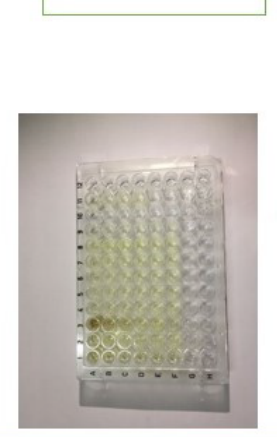

Enzyme inhibition evaluation

- AChE and BuChE inhibition assays

- MAO-A and MAO-B inhibition assays

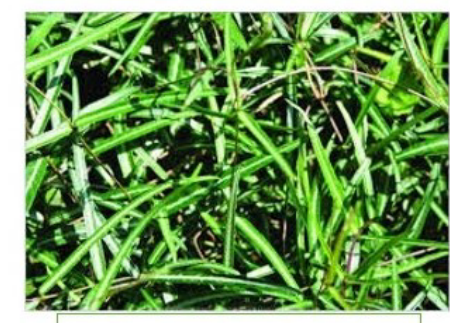

Hemidesmus indicus
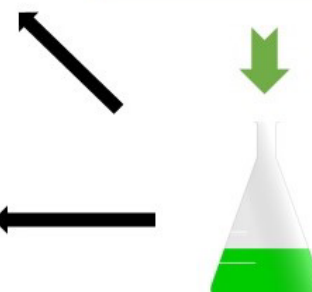

Dried roots were extracted with different solvents by cold maceration technique

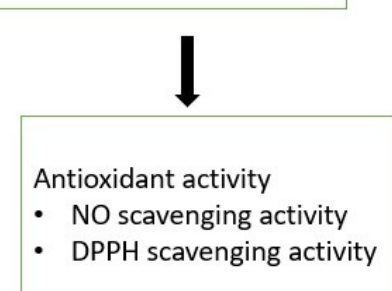

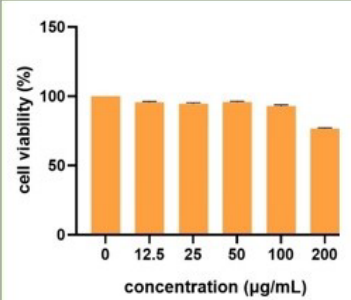

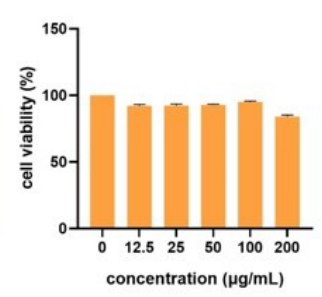

Cell viability assay
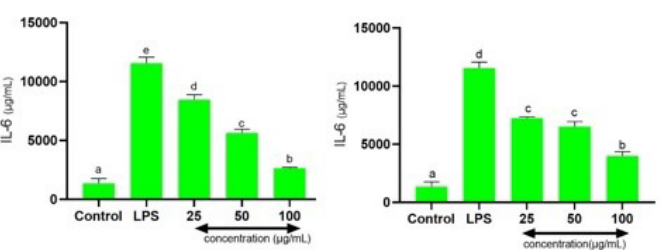

LPS

induced SHSY-5Y cell lines
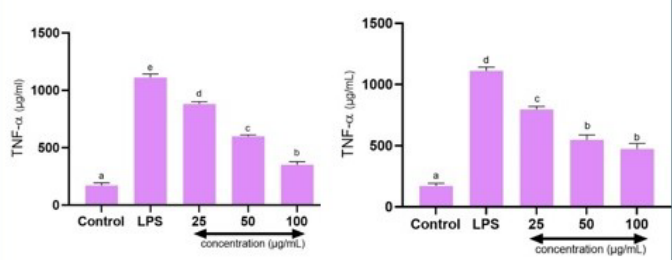

Anti-inflammatory activity

\section{ABOUT AUTHORS}
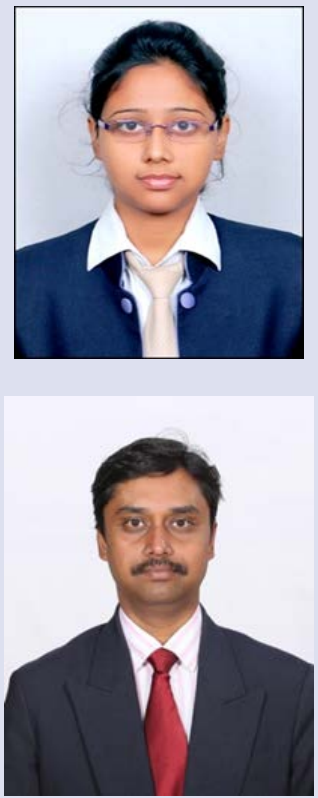

Swati Som: She is research scholar under the guidance of Prof. Sivasankaran Ponnushankar at JSS College of Pharmacy, Ooty. She has completed her master's degree in Pharmacology at Acharya and BM Reddy College of Pharmacy, Bangalore. Her area of research interest includes phytochemistry, herbal formulation and neuropharmacology. Currently she is working in the area of development of new molecules from herbal sources to target neurodegenerative disorders.

Dr Sivasankaran Ponnushankar is presently working as Professor and Head at Dept. of Pharmacy Practice, JSS College of Pharmacy, Ooty and involved in developing the clinical pharmacy education and concept in India. His area of research interest is community pharmacy practice research and social pharmacy; herb-drug interaction studies; pharmaceutical care and its outcome. He has published several research articles (International: 22; National: 53) in his area of research and contributed two book chapters. He is member of various professional national and international organizations. 


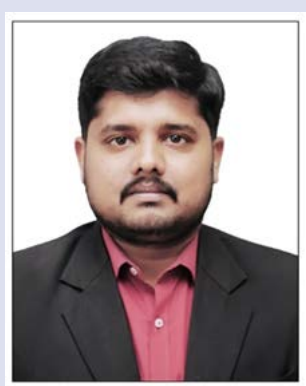

Dr. Justin Antony is presently working as Assistant Professor in JSS College of Pharmacy, Ooty. He has done his doctoral research in neuropharmacology especially in the area of brain angiotensin system and cerebral ischemia. His area of research interest is cerebral ischemia, neuroinflammation and excitotoxicity. He has research publications with cumulative impact factors of 12.41. Currently he is working in the area of development of new molecules to target neuroinflammation and neurodegenerative disorders. He is the life time member of Society of Neurochemistry, India.

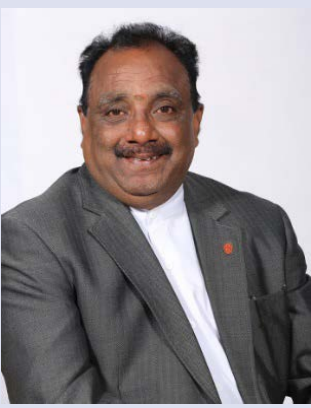

Dr. S.P.Dhanabal is currently Prof, Dept. of Pharmacognosy \& Phytopharmacy and Principal at the JSSCP, Ooty. His research interest is phytochemistry, herbal formulation \& standardization. He has 150 presentations in intl/national/regional seminars and published 95 journal articles. His research group consists of PG \& Ph.D students, International scientists under CV Raman/NAM S\&T/TATA ISTA JRD fellowships. He has received financial grants of about 1.50 Crore towards research grant and conduct of FDP/ Seminar/Workshop from AICTE, ICMR, DST, Govt. of India. He has been a Member of Scientific Services Committee of Indian Pharm. Congress for the past 06 years.

Cite this article: Som S, Antony J, Dhanabal SP, Ponnusankar S. Phytochemical Profiling of Hemidesmus indicus (L.) R. Br. ex Schult and its Antioxidant, Anti-Inflammatory and Neuroprotection Linked Enzyme Inhibitory Properties. Pharmacog J. 2021;13(1):196205. 